
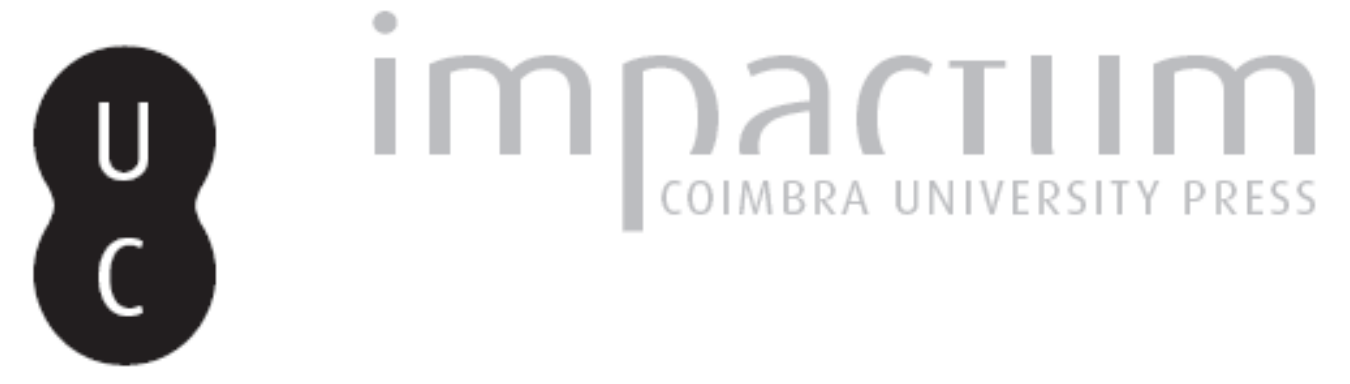

\title{
O quotidiano na clausura feminina eborense e a presença de população escrava: a fronteira entre o servir das portas adentro e das portas afora no período moderno
}

Autor(es): $\quad$ Conde, Antónia Fialho

Publicado por: Imprensa da Universidade de Coimbra

URL persistente:

URI:http://hdl.handle.net/10316.2/40665

DOI:

DOI:https://doi.org/10.14195/0870-4147_47_2

Accessed : $\quad$ 26-Apr-2023 14:15:37

A navegação consulta e descarregamento dos títulos inseridos nas Bibliotecas Digitais UC Digitalis, UC Pombalina e UC Impactum, pressupõem a aceitação plena e sem reservas dos Termos e Condições de Uso destas Bibliotecas Digitais, disponíveis em https://digitalis.uc.pt/pt-pt/termos.

Conforme exposto nos referidos Termos e Condições de Uso, o descarregamento de títulos de acesso restrito requer uma licença válida de autorização devendo o utilizador aceder ao(s) documento(s) a partir de um endereço de IP da instituição detentora da supramencionada licença.

Ao utilizador é apenas permitido o descarregamento para uso pessoal, pelo que o emprego do(s) título(s) descarregado(s) para outro fim, designadamente comercial, carece de autorização do respetivo autor ou editor da obra.

Na medida em que todas as obras da UC Digitalis se encontram protegidas pelo Código do Direito de Autor e Direitos Conexos e demais legislação aplicável, toda a cópia, parcial ou total, deste documento, nos casos em que é legalmente admitida, deverá conter ou fazer-se acompanhar por este aviso.

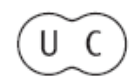




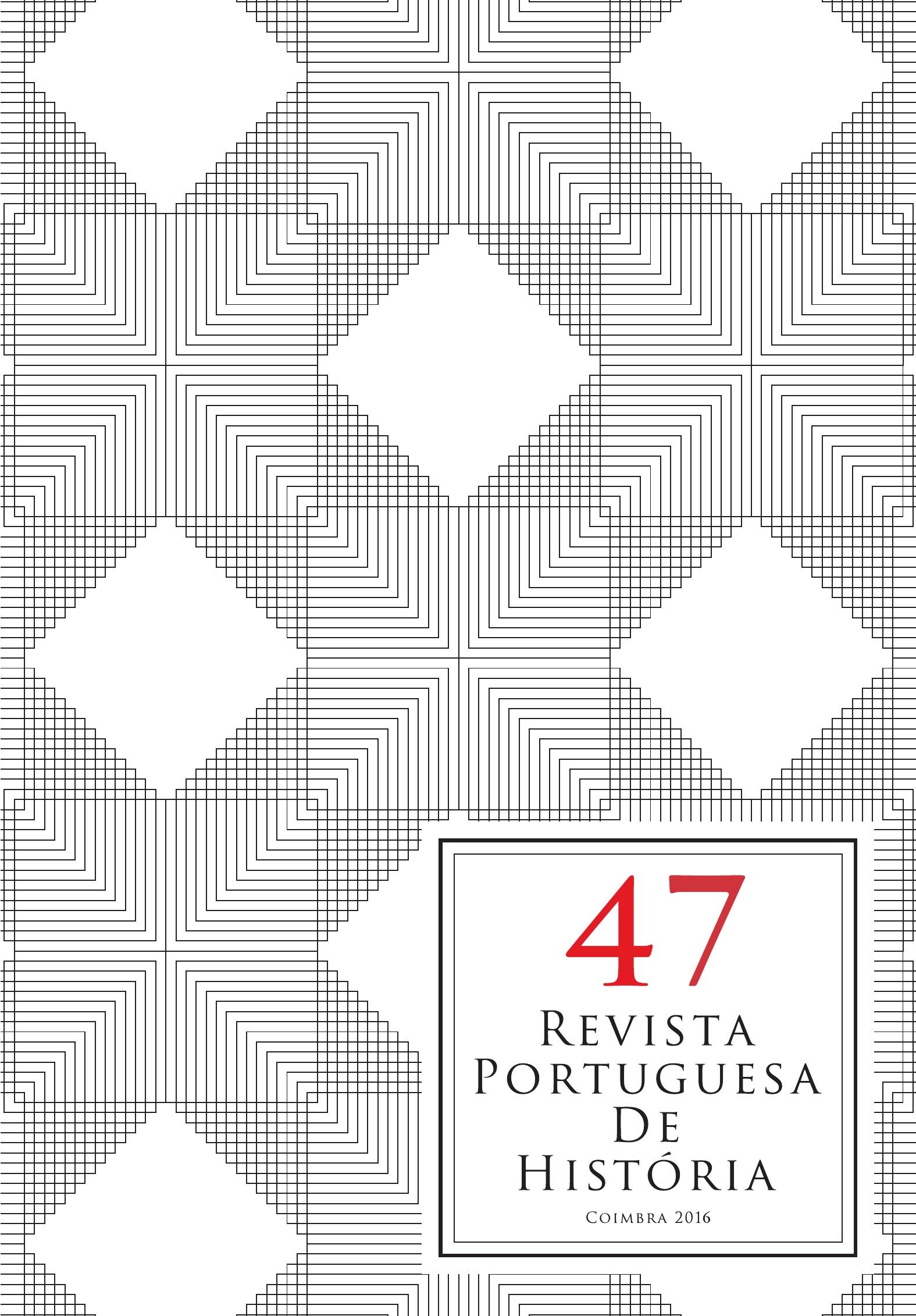




\title{
O quotidiano na clausura feminina eborense e a presença de população escrava: a fronteira entre o servir das portas adentro e das portas afora no período moderno
}

\author{
Everyday life in female religious communities in Évora \\ and the presence of slaves: the boundary between the in-house \\ and outdoor service in modern period
}

\author{
Antónia Fialho Conde \\ Universidade de Évora \\ antoniaconde@gmail.com
}

Texto recebido em/Text submitted on: 31/01/2016

Texto aprovado em/Text approved on: 22/06/2016

\section{Resumo:}

Apesar da existência de anteriores estudos, tanto em termos nacionais como regionais, e que demonstram a forte presença de escravos em Évora nos séculos XV e XVI, localizar a população escrava na documentação de instituições religiosas femininas da cidade e entender a sua condição de vida nessas comunidades não se revela fácil. Muitas das referências à sua existência são indiretas, ao fazerem parte de um dote ou doação (constando como bens a que se atribui um determinado valor), que podia ser testamentária, de partilhas e sentenças. São também de difícil perceção as tarefas desempenhadas no quotidiano de espaços claustrais, especialmente os femininos, sujeitos às exigências pós-tridentinas. Só com a apresentação de alguns casos, a juntar aos já conhecidos, poderemos sugerir algumas considerações sobre esta matéria.

Palavras-chave:

População escrava; Comunidades religiosas femininas; Évora; Período moderno.
Abstract:

Despite the existence of previous studies, both national and regional, studies that demonstrate a strong presence of slaves in Évora in the $15^{\text {th }}$ and $16^{\text {th }}$ centuries, locating them in documents from the city's female religious communities and understanding their living conditions in those communities is not an easy task. Many of the references to their existence are indirect and related to a dowry or donation (being mentioned as assets with an assigned value), which could be associated with a will, a partition or a sentence. It is also difficult to ascertain the tasks they performed in the everyday life of cloistered communities, particularly the female ones, subject to the post-Tridentine requirements. Only by presenting a series of cases, other than the ones that are already known, will we be able to suggest considerations on this matter.

Keywords:

Slave population; Female religious communities; Évora; Modern period. 


\section{Introdução}

Do estudo das minorias na Europa ocidental fazem parte as abordagens acerca da população não-livre ou escrava, cujo perfil se modificou no tempo histórico. Alessandro Stella assinala o caráter transversal da escravatura ao longo da história, em diferentes tempos e espaços ${ }^{1}$. Assim, na Idade Média a Europa conheceu a existência de escravos eslavos, turcos, russos, tártaros, sarracenos (e mouros durante a reconquista, no caso de Espanha), entre outros, cujo tráfico era assegurado por genoveses e venezianos; a queda de Constantinopla, associada ao declínio do comércio no Mediterrâneo, e especialmente à alternativa propiciada pelo escravo negro africano dado a conhecer pelos portugueses, alterou em definitivo este panorama, significando também a existência de dois termos que passaram a ser considerados sinónimos: negro e escravo. No caso português, o movimento dos escravos das Canárias para a Madeira teve início logo no século XIV, e os primeiros cativos negros chegaram à metrópole em 1441; antes da chegada dos negros, canários e marroquinos eram destinados aos trabalhos domésticos, sendo os chineses muito requeridos pelas suas qualidades culinárias ${ }^{2}$. O período moderno marcou a história de grandes cidades ibéricas como Sevilha, Córdova, Valência e Lisboa, em que os escravos são maioritariamente negros, sendo que, ao longo do século XVI, foi uma história que se dilatou por toda a Península Ibérica e pela Sicília.

Por outro lado, a questão da presença de população escrava nos espaços monásticos, especialmente nos femininos, tem atraído alguns estudos (e não apenas a nível europeu). Selamawitt Mecca, para a realidade etíope, afirma que "(...) sources recount tales of slaves in the monasteries and convents who helped nuns with the activities of daily life (...)”3. Na Croácia (e Dalmácia), a existência de escravos está documentada em testamentos e em cartulários de mosteiros desde o século IX, referindo as questões dos proprietários e das estruturas familiares em que os escravos viviam (solteiros ou em casais,

\footnotetext{
${ }^{1}$ Alessandro Stella, "L'esclavage en Andalousie à lépoque moderne", Annales, Économies, Societés, Civilisations, (1992), vol. 47, n 1. O autor distingue o trabalho forçado (exigido de populações conquistadas militarmente), os cativos de guerra com vista a um resgate, os servos da gleba, o trabalho pago a troco de alimentação e dormida, e a escravatura propriamente dita, em que um ser humano é propriedade de outro, que dele pode dispor como quiser.

${ }^{2}$ Carlos Frederico Montenegro de Sousa Miguel, “Escravatura”, Joel Serrão (dir.), Dicionário de História de Portugal, vol. II, Porto, Livraria Figueirinhas, 1981, p. 421-424.

${ }^{3}$ Selamawitt Mecca, "Women in Ethiopic Hagiographies", Proceedings of the 16th International Conference of Ethiopian Studies (ed. Svein Ege, Harald Aspen, Birhanu Teferra and Shiferaw Bekele), Trondheim, 2009, p. 1369.
} 
em família estruturada com filhos), o seu número e género (tendo os homens maior importância económica), as suas ocupações, a integração nas famílias proprietárias, a maneira como tinham chegado à condição de escravos (vendidos por mercadores ou familiares, por dívidas), ou o seu valor, entre outras ${ }^{4}$. Para a Península Ibérica, na região a sul de Valência, Mathew Carr ${ }^{5}$ sublinha o trabalho muito próximo da escravidão de milhares de muçulmanos que trabalhavam nos engenhos de açúcar, não apenas ao serviço de grandes famílias, como os Borgia, mas também de mosteiros, conventos e igrejas. Este Autor dá como exemplo o mosteiro de Valldigna, fortemente dependente do trabalho muçulmano na agricultura (cultivo de pomares e vinhas, nas colheitas) e na pastorícia. Ainda em Espanha, mais particularmente na Andaluzia, para o período moderno, Moreno Navarro sublinha ${ }^{6}$, a partir do estudo da Irmandade dos negros de Sevilha, a importância das informações fornecidas pelos registos paroquiais para o entendimento do percurso de vida dos escravos. No caso do registo de casamentos, verificou que os proprietários dos escravos procuravam que eles não casassem, apesar da legislação emanada de Trento que os consentia invito domino; os casamentos são, pois, um registo raro em relação aos batismos ${ }^{7}$, cujos registos também demonstram que cerca de $90 \%$ dos recém-batizados eram ilegítimos, tornando difícil a relação entre batismo e matrimónio. Ainda segundo Moreno Navarro, em finais do XV e inícios do XVI, em Córdova e Sevilha todos os grupos sociais possuíam escravos: nobreza, eclesiásticos e quase todos os ofícios de artesãos. No que concerne ao clero, incluíam-se o arcebispo, os membros do Cabido, curas, mosteiros e conventos que dispunham de escravos para seu serviço. Em Sevilha, dominicanos, mercedários, jesuítas,

${ }^{4}$ Para esta região, e entre os séculos XII e XIV, os escravos desempenham cada vez mais tarefas domésticas em vez de agrícolas, sendo substituídos paulatinamente por contratados; o tráfico de escravos era mantido pela procura da Itália e da Catalunha. Cf. Neven Budak, "Slavery in Late Medieval Dalmatia-Croatia: labour, legal status, integration", Mélanges de l'École française de Rome. Moyen Âge, 112/2, 2000, p. 745-760.

${ }^{5}$ Mathew Carr, Blood and Faith. The Purging of Muslim Spain, 1492-1614, London, Hurst \& Company, 2009, p. 97.

${ }^{6}$ Isidoro Moreno Navarro, La antigua hermandad de los negros de Sevilla: etnicidad, poder y sociedad en 600 años de história, Sevilla, Universidad de Sevilla/Consejeria de Cultura de Junta de Andalucia, 1997. Estes batismos devem ser também entendidos numa conjuntura de elevadíssima mortalidade infantil, a que o infanticídio não seria também alheio.

${ }^{7}$ Mesmo assim, esses casamentos aconteciam, ou entre escravos, ou em que um dos contraentes o era, podendo casar-se com um/uma escravo/a que ficara forro/a, ou com alguém de condição social humilde; trata-se de um fenómeno minoritário e contestado, pois procriar legalmente, fundar uma família, dava aos escravos direitos, como viver juntos, podendo ser considerado o matrimónio como uma antecâmara da liberdade. Esta questão é trabalhada por Alessandro Stella, "L'esclavage en Andalousie à l'époque moderne" ..., cit, p. 35-63. 
franciscanos, e a ordem de S. João de Deus possuíam-nos e vendiam-nos. Nos conventos femininos, em que havia mais escravos que nos masculinos, a situação era similar, com a particularidade de que o escravo podia entrar para o convento servindo a sua proprietária quando professasse.

Jeanette Pinto confirma também a presença de escravos em mosteiros e conventos na Índia portuguesa, apontando o exemplo do convento feminino de Santa Mónica de Goa, que teria 30 criados e escravos ${ }^{8}$.

\section{A dinâmica expansionista e a presença de escravos em Évora}

São diversos os estudos que têm abordado a questão da escravatura em Portugal ${ }^{9}$, sendo que, para o Alentejo (Montemor-o-Novo, Évora, Vila Viçosa e Faro) os trabalhos de Jorge Fonseca são fundamentais ${ }^{10}$.

${ }^{8}$ Jeanette Pinto, Slavery in Portuguese India, 1510-1842 $\square$, Universidade de Michigan, Himalaya Pub. House, 1992.

${ }^{9}$ A. C. de C.M. Saunders, A social History of Black Slaves and Freedmen in Portugal 14411555, Cambridge, Cambridge University Press, 1982 (edição portuguesa, História Social dos escravos e libertos negros em Portugal, 1441-1555, Lisboa, IN-CM, 1994); Alessandro Stella, Histoires d'esclaves dans la Péninsule Ibérique. Paris, EHESS, 2001; Anabela Silva de Deus Godinho, Lisboa Pré-Pombalina: a Freguesia da Sé Demografia e Sociedade (1563-1755) [Em linha]. Lisboa, ISCTE-IUL, 2007, Tese de doutoramento, Disponível em www:http://hdl. handle.net/10071/2830; António Borges Coelho, Ruas e Gentes na Lisboa Quinhentista, Lisboa, Caminho, 2006; Charles Verlinden, L'esclavage dans lEurope médiévale. Vol. I: Péninsule Ibérique. France, Bruges, 1955; Didier Lahon, "O escravo africano na vida económica e social portuguesa do Antigo Regime". Africana Studia. Porto, Ed. FLUP, n. ${ }^{\circ}$ 7, 2004; Idem, "Esclavage, confréries noires, sainteté noire et pureté de sang au Portugal (XVI et XVIII siècles)". Lusitania Sacra, 2. a série, 15, 2003, 119-162; Francis Dutra, "Ser mulato em Portugal nos primórdios da época moderna", Tempo [online], vol.16, n.30, 2011, p.101-114, ISSN 1413-7704. http:// dx.doi.org/10.1590/S1413-77042011000100005. Isabel Castro Henriques, A herança africana em Portugal, Lisboa, CTT, 2009; João Pedro Marques, Os sons do silêncio. O Portugal de oitocentos e a abolição do tráfico de escravos, Lisboa, ICS, 1999; José Ramos Tinhorão, Os negros em Portugal: uma presença silenciosa, Lisboa, Caminho, 1997, (2 ${ }^{\text {a }}$ ed); Maria Antónia Pires de Almeida, "Escravo", in Conceição Andrade Martins; Nuno Gonçalo Monteiro (orgs.), História do Trabalho e das Ocupações, vol. III, A Agricultura: Dicionário das Ocupações, Oeiras, Celta Editora, 2002, p. 180-186; Maria Emília Madeira Santos, "Mulatos, sua legitimação pela Chancelaria Régia no século XVI". Stvdia, Lisboa, n. ${ }^{\circ 53,1994 ; ~ M a r i a ~ d o ~ R o s a ́ r i o ~ P i m e n t e l, ~}$ Viagem ao fundo das consciências: a escravatura na época moderna, Lisboa, Colibri, 1995; Idem, "Ser escravo. Quadros de um quotidiano: dos trabalhos e dos dias", Chão de sombras, Lisboa, Colibri, 2010, p. 113-149; William D. Phillips, Slavery in Medieval and Early Modern Iberia, Parergon, vol. 31, $\mathrm{n}^{\circ}$ 2, 2014.

${ }^{10}$ Jorge Fonseca, "Senhores e Escravos no Algarve (1580-1700)", Anais do Município de Faro, no XXVI, 1996, p. 151-176; Idem, Escravos em Évora no Século XVI, Câmara Municipal de Évora, Colecção "Novos Estudos Eborenses" - 2, 1997; Idem, "Escravos em Vila Viçosa", 
A presença de árabes e judeus, a que se juntariam os escravos negros é, desde o século XVII, com Severim de Faria, apontada como causa da indolência da região e do abandono da agricultura. Estas ideias foram retomadas em finais do século XVIII: a decadência da agricultura e despovoamento causados pelos descobrimentos, como defendem Vandelli ${ }^{11}$, Soares de Barros ${ }^{12}$, António Henriques da Silveira ${ }^{13}$ ou Basílio Teles: "No tempo de D. Manuel (...) no sul só a introdução de bandos sobre bandos de escravos ia tapando os buracos, abertos entre a gente de trabalho pelos que se largavam nas armadas." ${ }^{\prime 4}$.

Pires de Lima ${ }^{15}$, na década de 40 do século XX considera que seriam entre 700 a 800 os escravos que chegariam anualmente a Portugal nos séculos XV e XVI; para António Brásio ${ }^{16}$, em 1554, 10\% da população de Lisboa era constituída por escravos, com confrarias em Lisboa e Lagos, Évora (1518), Elvas (1583) e Setúbal (1584). Sabe-se hoje que no século XVI algumas localidades do Alentejo tinham mais de $10 \%$ da população escrava. Jorge Fonseca ${ }^{17}$ apurou que, por exemplo, na paróquia de S.ta Maria da Vila, em Montemor-o-Novo, entre 1533 e $1600,17,24 \%$ das crianças batizadas eram filhas de escravas; afirma ainda que, em termos étnicos, na cidade de Évora no século XVI c. de 50\% dos escravos eram negros; mulatos/mestiços, baços ou pardos, c. de $30 \%$; c. de $10 \%$ oriundos

Callipole, $\mathrm{n}^{\circ} 5 / 6,1997$, p. 25-50; Idem, Os escravos nos conventos alentejanos", A Cidade de Évora, II Série, n. ${ }^{\circ}$ 6, Évora, Câmara Municipal, 2002-2006, p. 279-286.

${ }^{11}$ Alexandre A. Vandelli, Collecção de Instruções sobre a Agricultura, Artes e Industria, Lisboa, Typographia da Academia Real das Ciências, 1831- 1832.

${ }^{12}$ José Joaquim Soares de Barros, «Memoria sobre as cauzas da differente população de Portugal em diversos tempos da Monarquia", Memorias Económicas da Academia Real das Sciencias de Lisboa para o Adiantamento da Agricultura, das Artes e da Indústria em Portugal e suas Conquistas, tomo I, Lisboa, MDCCLXXXIX.

${ }^{13}$ António Henriques da Silveira, "Racional discurso sobre a Agricultura e População da Província do Alem-Tejo”, Memorias Economicas, I, Lisboa, 1789.

${ }^{14}$ Bazílio Telles, O problema agricola: crédito e imposto, Porto, Chardron, 1899.

${ }^{15}$ J. A. Pires de Lima, Mouros, Judeus e Negros na História de Portugal, Lisboa, 1940.

${ }^{16}$ Antonio Brásio, Os Pretos em Portugal, Lisboa, Agência Geral das Colônias, 1944. Quanto às confrarias, se a primeira foi a do convento de $\mathrm{S}$. Domingos de Lisboa, ainda no século $\mathrm{XV}$, fundada por brancos, em 1551 ela estava dividida em duas, sendo uma dos pretos forros e escravos de Lisboa. Mas todas as localidades com maior concentração de negros as possuíam. Ainda segundo António Brásio, a segunda a surgir foi a Irmandade do Rosário dos Pretos de Évora, logo em inícios do século XVI, surgindo também em Alcácer do Sal, Setúbal, Vila Viçosa, Grândola, Montemor-o-Novo, Estremoz e Elvas, e no Algarve. A Irmandade de Nossa Senhora do Rosário dos Pretos de Évora mantinha-se ainda bastante ativa em Évora no último quartel do século XVII e inícios do século XVIII. Cf. ADE, Notarial de Évora, Livro 762, fls. 46, 144. Os seus mordomos compravam, por esta altura, a capela do Rosário e suas sepulturas aos frades de S. Domingos. Cf. ADE, Notarial de Évora, Livro 825, fl. 176.

${ }^{17}$ Jorge Fonseca, Escravos em Évora no século XVI..., cit., 1997. 
do norte de África; $6 \%$ indianos; $0,34 \%$ chineses e a mesma percentagem de judeus, sendo os indianos e os chineses os mais valiosos. Num documento de 1535, Nicolau Clenardo ${ }^{18}$, mestre do Infante D. Henrique, escreveu sobre o que presenciava, particularmente em Évora, num texto já muito conhecido: “Os escravos pululam por toda a parte. Todo o serviço é feito por negros e mouros cativos (...) Dificilmente se encontrará uma casa onde não haja pelo menos uma escrava destas. É ela que vai ao mercado comprar as coisas necessárias, que lava a roupa, varre a casa, acarreta a água e faz os despejos à hora conveniente".

Em relação aos proprietários dos escravos, se, em termos nacionais, a Igreja é a instituição proprietária de escravos por excelência, c. de 31,8\% do total, apenas $10 \%$ é do clero regular; nas comunidades femininas, muitas das futuras religiosas oriundas da nobreza ingressavam na vida monástica acompanhadas das suas escravas e/ou criadas particulares ${ }^{19}$. Em Évora, para o século XVI, tomámos como ponto de partida o quadro traçado por Jorge Fonseca ${ }^{20}$. Se o autor alerta para o facto de se tratar de uma amostra, dado que os donos de escravos com condição ou profissão conhecida são apenas um terço do total dos proprietários, dentro do clero regular e secular são identificados 183 proprietários, $(18,48 \%$, apenas uma décima abaixo dos proprietários ligados à agricultura). O subgrupo mais significativo era o dos clérigos (155), seguido das igrejas e conventos (17) e depois as freiras e recolhidas (11). Entre as casas religiosas masculinas de Évora são citadas como proprietárias de escravos a Cartuxa, $\mathrm{N}^{\mathrm{a}} \mathrm{Sr}^{\mathrm{a}}$ do Carmo, $\mathrm{N}^{\mathrm{a}}$ Sr. ${ }^{\mathrm{a}}$ do Espinheiro, $\mathrm{N}^{\mathrm{a}}$ Sr. ${ }^{\mathrm{a}}$ da Graça, e os jesuítas, não sendo nomeados os conventos das Mercês, Remédios, Santo António da Piedade, S. Francisco e S. Domingos. Entre as femininas, são citados os conventos do Paraíso, de Santa Catarina de Sena, Santa Clara, Santa Mónica, Santa Marta e o mosteiro de S. Bento de Cástris (de entre as femininas, não são nomeados os conventos do Salvador, S. José e Calvário), sendo os mais citados, segundo o autor, o Espinheiro e o Paraíso. Jorge Fonseca observa ainda a coincidência de género entre os proprietários e os escravos, em termos de casas religiosas, registando algumas exceções, como em S. Bento de Cástris, onde em 1565 existia um escravo no pátio do mosteiro, António Mendes, casado com o consentimento das religiosas com Brites Lopes; nesse ano, foi batizada uma filha de ambos ${ }^{21}$. Também no convento do Paraíso as religiosas tinham um escravo, Vasco Correia,

${ }^{18}$ Manuel Gonçalves Cerejeira, Clenardo e a Sociedade Portuguesa do seu tempo, Coimbra, Coimbra Editores, 1949, (3 $3^{\text {a }}$ ed. act.).

${ }^{19}$ Cf. Didier Lahon, "O escravo africano na vida económica e social portuguesa do Antigo Regime"...., cit., p. 73-100.

${ }^{20}$ Jorge Fonseca, Escravos em Évora no século XVI...., cit., p. 38.

${ }^{21}$ Jorge Fonseca, Escravos em Évora no século XVI..., cit., p. 44. 
que, em 1542, foi pai de Domingos, filho de Luísa Correia, também escrava no mosteiro, não sendo legitimamente casados. Estes dois casos indiciam uma provável vida marital (um dos casais era casado) fora do espaço de clausura.

A presença de escravos no quotidiano da cidade de Évora pode ser apreciada de distintas formas, mas a questão dos proprietários, apesar do seu caráter de amostra, é muito significativa, dada especialmente a sua heterogeneidade. Assim, em 1575, o pintor Sebastião Jorge tinha ao seu serviço uma escrava, Isabel, sendo documentado o batismo do filho da escrava, Manuel: “(...) Aos 9 de dizembro de 75. Baptizej e puz os santos oleos a manoel filho de Izabel escraua de bestião Jorge pimtor foi Padrinho Antonio Galuão \& Madrinha Anna roiz (...)”22. Como sabemos, muitas vezes, o batismo registava-se em escravos já adultos, não sendo indicada a mãe, como foi o caso, em 1588, de Pedro, escravo do pintor Francisco Joã $0^{23}$. Alguns anos antes, em 1556, fora registado o enterro da escrava de outro pintor, mestre Manuel ${ }^{24}$. Assim, junto dos pintores, alguns de condição humilde, mas outros de folgada situação económica e com reconhecimento social na cidade, como era 0 caso de Francisco João (pertencia à Irmandade da Misericórdia de Évora, sendo Irmão e mordomo), a posse de escravos indicia precisamente que a sua situação económicosocial era desafogada.

Como um dos diversos exemplos da pertença de escravos pela nobreza estabelecida em Évora no século XVI, temos que, em 25 de novembro de 1598, quando foi feita uma Visitação ao oratório nas casas de D. Brites de Vilhena junto à catedral de Évora por Gaspar Gomes, visitador do Arcebispado, este encontrou

“(...) o dito Oratorio sem frontal, nem ornamento algum nem pedra d'ara, somente estava hum retavollo pintado com huã imagem de Nossa Senhora d'asumpsão cuberto com huas corrediças de bertangil vermelho, e disse huã escrava que se não dezia nelle agora Missa por a dita dona Brites estar agora em huã sua herdade na Oliveira e mandar levar pera la todos os ornamentos, e couzas do dito oratorio, e tinha hum Altar grande de madeira com hum caixão fechado no mesmo altar (...)" ${ }^{25}$.

O documento revela uma dualidade muito presente entre as famílias nobres de Évora, a existência de uma residência na cidade e outra em zona rural, no seu termo, deslocando bens e criadagem sempre que alteravam o local de residência.

${ }^{22}$ Arquivo Distrital de Évora (doravante ADE), "Livro de Batizados de Santo Antão", 7, fl.25 v. .

${ }^{23}$ ADE, "Livro de Batizados de Santo Antão", 8, fl.49 v. .

${ }^{24}$ ADE, "Livro de Defuntos da Misericórdia (1556-72)" (caderno sem numeração).

25 Biblioteca Pública de Évora (doravante BPE), Fundo Manizola, Cód.-61, "Visitação dos Oratórios de Évora de 1591", fl. 94. 


\section{A população escrava nas comunidades religiosas femininas de Évora}

A questão do acompanhamento de religiosas oriundas da nobreza pelas suas escravas particulares conheceu alguns exemplos manifestamente exagerados: em Lisboa, em 1619, a comendadeira de Santos tinha para o seu serviço pessoal 8 criadas e 2 escravas; toda a comunidade (18 freiras e 26 noviças) era servida por 69 criadas, entre as quais 7 escravas $^{26}$.

Para os mosteiros da Ordem de Cister, no Regimento de 1564 do Cardeal D. Henrique enquanto abade comendatário de Alcobaça, encontramos dois parágrafos, o $10^{\circ}$ e o $12^{\circ}$, bem explícitos em relação à existência de escravas nos mosteiros de religiosas: as abadessas não podiam, sem consentimento do demais convento (entenda-se comunidade), forrar escravos ou escravas, tal como não poderiam dar licença para que nenhuma religiosa as tivesse, pertencendo ao mosteiro o senhorio das escravas, podendo eventualmente ser cedidas para auxílio a doentes, com licença da abadessa ${ }^{27}$. Repare-se que a referência é feita apenas para escravas, não para escravos. Porém, a Congregação Autónoma de Alcobaça (1567), representada na realidade eborense pelo mosteiro de S. Bento de Cástris, admitiu a existência de escravos de ambos os sexos no espaço conventual, intra e extra clausura. Neste mosteiro, em 1579, a então abadessa, D. Brites Pereira e mais religiosas, com autoridade que tinham do P. frei Manuel, visitador da Ordem, respeitavam a vontade de Maria Brás, religiosa no mosteiro, de dar alforria a

"Joana, sua escrava preta da guiné, molher de idade de vinte anos pouco mais ou menos, molher que fala bem e he meuda do pelo e tem as orelhas furadas, lhes aprazia como de feito logo aprouve de forrarem como como de feito logo forraraõ a dita Joana e per respeito de duas filhas que per si deu ao dito, luisa mulata de quatro anos pouco mais ou menos e a antónia preta de idade de hum ano e isto com tal condição que a dita Joana criar a dita antonia sua filha ate idade de tres anos perfeitos e asy que a dita Joana seja seja obrigada a servir a dita maria bras em sua vida $\mathrm{E}$ mais que nom case com escravo cativo e nom cumprindo isto ausentandose do dito serviço que esta carta the nom valha e que cativa como dantes estava a dita ordem e per falecimento da dita maria bras a dita Joana fique forra e livre sem nenhuma sujeição nem cativeiro ella e o que della nacer da feitura desta carta pera diante e possa fazer desy o que

\footnotetext{
${ }^{26}$ Cf. Didier Lahon, "O escravo africano na vida económica e social portuguesa do Antigo Regime", ..., cit., p. 92.

${ }^{27}$ Saul António Gomes, Visitações a mosteiros cistercienses em Portugal, séculos XV e XVI, Lisboa, MC/IPPAR, 1998, p. 425-426.
} 
lhe aprouver como se forra e lyvre nacera do ventre de sua mãe e a dita Joana que presente estava aceitou a lyberdade e alforria com as ditas condições as quais se obrigou de comprir em servir a dita maria bras como dantes enquanto ella viver e que recebia muito grado em dar e lhes beijava as mãos pella mercê que lhe fazião"

Um documento profundamente esclarecedor, em que além das alusões ao seu aspeto físico (é miúda de pelo) e alguma formação intelectual (mulher que fala bem), estabelece claras orientações para a vida futura de Joana, a quem era concedida alforria: não casar com escravo cativo (se o fizesse perdia a alforria), podendo portanto casar com um ex-escravo; por morte da religiosa não só ela continuaria forra bem como seus futuros filhos (as que já tinha antes continuariam escravas, ficando claro que as dera ao mosteiro); deveria servir vitaliciamente a religiosa. Repare-se, porém, como para a escrava que circulava na clausura o documento não exclui a futura existência de filhos, desde que não fossem de escravo cativo, embora existindo indicações das Juntas e Capítulos de que não deveriam circular crianças na clausura, após visitações realizadas ao mosteiro, indiciando que tal acontecia.

Outro caso, no mesmo mosteiro, que explicita a permeabilidade do espaço claustral parte de uma sentença, que se baseia numa carta de alforria ${ }^{29}$. Joana Nogueira, mulher preta, escrava cativa, natural de Cabo Verde, viera de África para a cidade de Lisboa e fora doada a uma religiosa de Cástris, trazendo para o mosteiro uma filha, sua homónima, de 4 ou 5 anos e que nascera já em Lisboa, onde fora batizada. Joana servia o mosteiro

"indo a fonte e ao Rossio e indo a dita cidade de evora a tudo o que lhe mandavam (...) e vimdo a dita freira a falecer deixou e ficou a dita Joana nogueira a Nova e molher que foi delle embargante por escrava e cativa do dito mosteiro e caza delle e temdo a outra Religiosa por esmolla e serviço de Deus e particular amor e afeição que lhe tinha tomou e deu trinta mil réis por sua liberdade e com elles a forrou e ficou forra" ${ }^{30}$.

Do texto fica a ideia de que a escrava Joana servia a comunidade (e não apenas uma religiosa) em serviços vários, sendo que sua filha recebera carta de alforria e saíra do mosteiro para casa nobre, servindo de Mestra de meninos e de costura na casa da condessa de Tentúgal. Apercebemo-nos, na descrição da ocupação da escrava, da sua formação cultural, ao ser responsabilizada como mestra de meninos. A ex-escrava recebera como dote 12.000 réis de casamento,

\footnotetext{
${ }^{28}$ ADE, Notarial Évora, Livro 171, fls. 51v.-52v.

${ }^{29}$ BPE, Livro 18 Fundo S. Bento, doc. $n^{\circ} 23$.

${ }^{30}$ BPE, Livro 18 Fundo S. Bento, doc. $n^{\circ} 23$, fls. 5 v., 6.
} 
que lhe haviam sido dados por Mécia Luís e, por sua morte, uma sentença da Relação estabelecia que os bens da falecida pertenciam a um seu irmão que estava na Índia, estabelecendo-se que se entregariam estes bens ao seu curador, e o mosteiro a nada tinha direito. Toda esta informação surge numa resolução do tribunal que acompanha este processo e surge na sequência de uma queixa do seu marido acerca do destino dos bens de Joana Nogueira (a nova).

Como acima sublinhámos, a presença de escravos de ambos os sexos nos mosteiros e conventos é proveniente de legados testamentários, dotes ${ }^{31} \mathrm{e}$ partilhas/heranças, a que acrescentamos as sentenças ${ }^{32}$, sendo os conteúdos dos testamentos uma importante fonte para a transação de escravos em Évora; a este leque de operações Jorge Fonseca acrescenta a cedência precária de trabalho, a compra, a troca e a reprodução das escravas ${ }^{33}$.

Quanto às heranças obtidas por religiosas em clausura, temos, para $\mathrm{S}$. Bento de Cástris, a 15 de maio de 1495, uma carta de partilhas entre os quatro netos feita por João Touregão, escudeiro do rei, e sua mulher, Brites Martins. Os escravos referidos são ${ }^{34}$ : Diogo, escravo negro, moço, avaliado em 6.000 reais; Maria, escrava negra, ainda moça, avaliada em 8.000 reais; outra escrava negra, de nome Catarina, avaliada em 10.000 reais; uma escrava baca (sic), de

${ }^{31}$ Jorge Fonseca cita os exemplos do Paraíso, em que D. Inês de Melo, em 1572, ao ingressar no convento levou uma mulata de 5 anos, para servir o convento, ou de João Martins Gago que, tendo duas filhas no convento de jerónimas de Viana doou ao convento uma escrava parda, para servir as madres e não tornar a sair dele; neste mesmo convento, e fazendo parte do dote de Beatriz Dias, consta uma escrava preta, Helena. O Autor cita que também poderiam ser comprados ou vendidos, por exemplo quando fugissem, citando ainda a doação de um escravo índio ao recolhimento de Santa Marta em Évora, em 1546. Jorge Fonseca, Escravos em Évora no século XVI..., cit., p. 45, 46 e 65.

${ }^{32}$ No testamento de António Ferreira da Câmara, em 1674, em que é nomeado como testamenteiro o Bispo de Targa, constam inúmeras obrigações de cariz eclesiástico a cumprir em vários altares e igrejas da cidade (como as mil missas por diversos sacerdotes especialmente às almas do Purgatório e as missas a seus pais), os dotes para casamento de 16 órfãs honradas, os bens doados a criados, e a alforria da sua escrava Sebastiana, depois da sua morte; num codicilo ao testamento, acaba por não dar a liberdade à escrava e por a legar aos seus herdeiros. Arquivo Distrital de Évora, Testamentos, Cx. 11, nº 84. Também num testamento conjunto, em 1673, de António Pinto Leoniz e Joana Batista Leoniz, irmãos, ambos sem herdeiros, libertam uma negra, Isabel, por morte de ambos. Arquivo Distrital de Évora Testamentos, Cx. 10, no 93.

${ }^{33}$ Jorge Fonseca, "Os escravos nos conventos alentejanos", A Cidade de Évora, II Série, n. ${ }^{\circ}$ 6, Évora, Câmara Municipal, 2002-2006, p. 279-286. Sobre esta matéria, cf. ainda Christiana Martins, "O segredo dos escravos reprodutores", Jornal Expresso 5 dezembro 2015, primeiro caderno, p. 20, 21.

${ }^{34}$ Assim, dos 9 escravos, apenas um seria branco; João, não é explicitamente branco, bem como Beatriz, ambos com patronímico. Estes dados confirmam que João Touregão, abastado escudeiro, era dono de escravos negros, mouros e brancos. (Leitura do Dr. André Silva). 
nome Fátima, avaliada em 10.000 reais (provavelmente moura); uma escrava menina, filha da dita Fátima, avaliada em 4.000 reais; uma escrava, de nome Beatriz Eanes, que fica forra, em 10.000 reais, e em que não é referida a cor; um escravo branco, de nome João Rodrigues, avaliado em 12.000 reais; outro escravo negro, moço, chamado Francisco, avaliado em 8.000 reais brancos; um último escravo, também moço, chamado Brás, avaliado em 7.000 reais (provavelmente, negro, embora não refira a cor). Entre os bens das netas, Beatriz Touregã, Maria Touregã e Clara Gonçalves, já religiosas em Cástris, couberam, para Clara, a escrava Fátima para Maria o escravo Diogo.

Após a morte da avó, Brites Martins, a 23 de abril de 1526, as partilhas foram feitas entre o neto João, as duas netas ainda vivas, Beatriz e Maria ${ }^{35}$, e o convento do Espinheiro, a quem a avó deixara a terça, solicitando vir a ser sepultada no seu cruzeiro. A avó fizera inventário em 1511, quando testara, sendo que no testamento tornava forros 4 escravos (Joana, João, Bartolomeu e Jerónimo), determinando que, depois da sua morte, deveriam servir o neto. Entre os bens das religiosas constam, para cada uma, 3.333 reais e 2 ceitis da venda de um escravo, além dos muitos bens de raiz e alguns móveis.

Em setembro de $1539^{36}$ a documentação esclarece ainda que, além destes bens originados dos avós, quando Brites e Maria Touregã haviam entrado para o mosteiro levaram consigo três escravas para as servirem (Helena, Juliana e Violante, cujas mães já haviam servido os Touregãos) e a quem tinham passado carta de alforria na altura, passando a servi-las como criadas, e não como escravas, dentro do mosteiro. Neste caso, aquele em que maior número de escravos (negros, mouros e brancos) são citados no longa relação desta família com este mosteiro, alguns deles alforriados.

Também entre os bens herdados por D. Inês da Silva, outra religiosa em S. Bento de Cástris, consta a referência a escravos. Em 1602 $2^{37}$, por morte de sua avó, D. Violante da Silva, a religiosa recebera entre diversos bens 20.000 reais por uma escrava mulata. No caso desta religiosa, a complexidade do processo de partilhas iniciara-se já antes, em $1597^{38}$, com a morte de uma tia, D. Maria Mendes, casada em segundas núpcias com Duarte de Melo Pereira. Com a morte da tia desta religiosa, o mosteiro fez-se representar na partilha dos bens por frei Lamberto, procurador da instituição e da religiosa. Entre os bens móveis, couberam ao mosteiro 2 escravos: Belchior, avaliado em 75.000 reais fl. 179 .

${ }^{35}$ BPE, Livro 20 Fundo S. Bento, peça 72; BPE, Livro de Tombo do mosteiro de S. Bento,

\footnotetext{
${ }^{36}$ BPE, Livro 17 Fundo S. Bento, doc. 69.

${ }^{37}$ BPE, Livro 21 Fundo S. Bento, peça 33.

${ }^{38}$ BPE, Livro 21 Fundo S. Bento, peça 1.
} 
e Francisco, em 50.000 reais; só em 1617, a 20 de julho ${ }^{39}$, a Relação de Lisboa concretizou a partilha dos bens, por sentença, a partir do Inventário realizado, constando os 2 escravos no quinhão de D. Inês.

No caso dos dotes que incluíam escravas podem também ser exigidas condições de tratamento futuro. Em 28 junho de 1646, sendo abadessa em S. Bento de Cástris D. Ana de Faria de Almeida, no dote de 1000 cruzados de Inês da Conceição, o dotador, seu pai, Manuel Rodrigues Santiago, de Arraiolos, nomeia a filha como herdeira dos seus bens (a mãe, Isabel Luís, já falecera); doou-lhe uma escrava para a servir, e que, por sua morte, o mosteiro não podia vender nem meter fora ${ }^{40}$, o que poderia precisamente significar um encargo futuro para a instituição, dada a necessidade de assistência e sustentação da escrava quando já não tivesse condições para servir o mosteiro.

No convento dominicano do Paraíso de Évora, no último quartel do século XVI, no título de bens e propriedades que trouxera Francisca de Faria, no valor de 460.000 réis obtidos por ordem régia após demanda com o cunhado, D. Fradique, “(...) uma parte (...) nos escravos que nam podemos vender, digo, que nam podemos aver porque ficaram forros. (...) Item herdou mais duas escravas que sam ja falecidas e outra que depois saiu forra." ${ }^{41}$. Neste mesmo convento, c. de 1575 , entre os bens que trouxera a madre Helena do Rosário constava também uma escrava, avaliada em 20.000 réis $^{42}$. Quatro anos depois (1579) ingressou neste convento D. Maria de Távora, filha de João de Sepúlveda e de D. Constança de Távora, e viúva de Pedro Álvares de Carvalho, capitão-mor e governador de Mazagã $0^{43}$. Ao entrar no convento trouxera uma filha, para quem também assegurou o sustento na comunidade, idêntico ao de uma aia da criança que entrou na instituição na mesma altura. Em 1580 (1 de outubro) D. Maria professou ${ }^{44}$.

As religiosas que possuíam escravas (em Santa Clara, no Paraíso, Santa Catarina $^{45}$ ) passavam normalmente por sua morte à instituição. Porém, havia freiras que tinham escravos, como Inês de Cobelos, religiosa no Salvador, que em 1566 libertou um seu escravo baço, certamente na altura do testamento e antes da profissão. Catarina Viegas, recolhida em Cástris, originária de Serpa, possuía escrava e escravo, a que dá destinos diferentes ao testar. Em 17 de agosto

\footnotetext{
${ }^{39}$ BPE, Livro Tombo do mosteiro de S. Bento de Cástris, fl. 227.

${ }^{40}$ BPE, Cód. CXXXI/2 - 27, fls. 23-29.

${ }^{41}$ BPE, Livro 1 do Paraíso, fl. 31.

${ }^{42}$ BPE, Livro 1 do Paraíso, fl. 34 v.

${ }^{43}$ BPE, Livro 1 do Paraíso, fls. 37v., 38.

${ }^{44}$ BPE, Livro 1 do Paraíso, fl. 41.

${ }^{45}$ Jorge Fonseca, Escravos em Évora no século XVI, ..., cit., p. 47.
} 
de 1617 , no seu testamento ${ }^{46}$, feito antes de professar no locutório do mosteiro, sendo maior de 25 anos, deixou ao mosteiro 80.000 réis para se empregarem em bens de raiz, indicando os 3 irmãos como testamenteiros. No testamento, declara que "minha escrava Esperança me fique em minha tença e por minha morte a deixo às duas [uma sobrinha e uma prima que tinha no mosteiro] e se ela não servir a minha vontade mando que ma vendam e me merquem outra que me satisfaça" ${ }^{47}$, ficando ao mosteiro depois da sua morte. Determina ainda que

"hum escravo indio que tenho, por nome António, que por minha morte natural fique forro e em satisfação de alguns serviços que faça a meus irmãos, mando a meu irmão Manuel da Cruz ou a quem pessuir a Capela de missa cotidiana o sustente de tudo o que lhe for necessario e assim lhe rogo que lhe faça muito boa companhia e o trate muito bem emquanto o dito escravo viver." ${ }^{48}$.

Portanto, à escrava não concedia a liberdade, devendo servi-la ou às suas familiares; no testamento faz ainda questão de sublinhar que a escrava a devia servir de acordo com a sua vontade, e se não a satisfizesse o mosteiro poderia vendê-la e comprar-lhe outra que a servisse a seu gosto. No caso do escravo índio, concede-lhe a alforria por sua morte, devendo, como era habitual, passar a servir os irmãos, sendo que solicita que o tratem muito bem.

A exigência em relação ao serviço prestado é bastante frisada, como, em 15 de junho de 1582 aquando da escritura de entrega e quitação de dote de religiosa ${ }^{49}$ que fez o mosteiro de Cástris a Pero Gonçalves de Camões, fidalgo da Casa Real, morador no Alandroal, sobre D. Catarina, sua filha. Entre outros bens, Pero Gonçalves dera à filha uma escrava, por nome Maria, que lhe ficara por testamento da mãe (Isabel):

"E por quanto não herão contentes o dito convento do serviço della lha tornavão logo a entregar pera que elle a leve e faça della o que quiser e elle dito pero gonçalves lhe daa logo pera outra escrava dezasseis mil reis com que a comprarão e a dita d. catarina se serviria della em sua vida e por sua morte ficara cativa no dito convento." ${ }^{50}$.

Por outro lado, a preocupação com o tratamento dos escravos surge na documentação do mosteiro cisterciense de Évora em 1492, a 11 dezembro, embora não se trate de bens do mosteiro ou das suas religiosas ${ }^{51}$. Inês Fernandes Gramacha, mulher de Vasco Arnalho, deixa expresso no seu testamento (onde

\footnotetext{
${ }^{46}$ BPE, Livro Tombo S. Bento de Cástris, fl. 381.

${ }^{47}$ BPE, Livro Tombo S. Bento de Cástris, fl. 383.

${ }^{48}$ Ibidem.

${ }^{49}$ BPE, Livro 29 Fundo S. Bento, fl. 72.

${ }^{50}$ BPE, Livro 29 Fundo S. Bento, fl. 73 v.

${ }^{51}$ BPE, Livro Tombo do mosteiro, fl. 373. BPE, Pasta S. Bento 2, no 80.
} 
também menciona o mosteiro) que a sua escrava Isabel ficasse forra 5 anos após a sua morte, dando-lhe estrebaria, palheiro, casa de poço, enxoval (que especifica, com cama de roupa que valesse 4.000 reais) e peças de roupa (uma fraldilha de Bruges, um manto e um saio preto), ou seja, conferia-lhe liberdade, tornava-a proprietária de alguns bens e concedia-lhe enxoval, propiciando-lhe condições de matrimónio. Inês Gramacha determinava ainda no testamento a concessão de alforria a Bento e Agostinho, escravos seus, com condição que, depois da morte da testadora, servissem o marido; o mesmo para Johane e Inês, também escravos seus. Inês Gramacha teria, pois, 5 escravos - 3 homens e 2 mulheres, preocupando-lhe especialmente com o futuro de uma delas.

Num instrumento de dote, esmola e obrigação ao mosteiro de S. Bento de Cástris $^{52}$, a 1 de junho de 1581, sendo abadessa D. Brites Pereira, Heitor de Melo, do Conselho d'El rei, morador em Évora, expressa a vontade do irmão António de Melo, alcaide-mor de Castro Marim, de colocar no mosteiro uma filha com cerca de 10 anos, filha de D. Francisca Coutinha, já falecida. Na entrada, o tio doou-lhe uma escrava para a servir e para servir a casa. Professando, o mosteiro receberia 1.000 cruzados de dote e, se não professasse, sairia com a escrava e tudo o que levasse para o mosteiro, não dando o dote principal (1.000 cruzados). Tornamos a encontrar referência a Maria Coutinho, futura abadessa no mosteiro, cerca de um ano depois, a 19 de março de $1582^{53}$, na casa do Parlatório do mosteiro, estando aí reunidos o Abade Geral da Ordem, Dr. P. Frei Lourenço do Espírito Santo, o Pe. Frei Aleixo da Luz, pregador e confessor do mosteiro, o Dr. Lançarote Leitão Perestrelo, juiz de fora dos órfãos com alçada por el-rei na cidade de Évora, e Francisco Monteiro, tutor e curador de D. Maria Coutinha, que já tinha acabado o ano de noviciado, preparando-se para professar. É descrita a diversa fazenda que possui, onde constam

"duas escravas mulatas convem a saber maria e francisca as quais tinha no dito convento consigo que ella ficaria senhora pera si e poder servir della a francisca sem o ditto mosteiro lhe ir a isso à mão e quanto a maria escrava disse ella dona maria e seu tutor que a davão ao dito Convento pera o servir sem o dito convento ha poder trespasar nem vender a pesoa allgua sallvo se for pera the comceder lliberdade. ${ }^{54}$.

\footnotetext{
${ }^{52}$ BPE, Cód. CXXXI/2-1, doc. 7.

${ }^{53}$ BPE, Livro 29 Fundo S. Bento de Cástris, fl. 74v.

${ }^{54}$ BPE, Livro 29 Fundo S. Bento de Cástris, fl. 76.
} 
Frisemos a questão da propriedade sobre Francisca, a que o mosteiro "não poderia deitar a mão", abdicando a futura religiosa de Maria a favor do mosteiro, mas limitando também a atuação da instituição em relação à escrava ${ }^{55}$.

A cláusula de servir as religiosas "de portas adentro", "dentro no mosteiro" ou das "portas afora" surgia muitas vezes em doações de escravos/as a mosteiros femininos, definindo espaços distintos de circulação no espaço da clausura. Vejamos alguns exemplos. Ao convento da Saudação em Montemor-o-Novo foram doadas três escravas em testamento por D. Elvira de Mendonça, mulher de D. Fernão de Martins Mascarenhas, capitão de ginetes de D. João III e alcaidemor da vila, que doou também 3 escravos para as servirem das "portas afora" ${ }^{56}$.

Para o mosteiro de S. Bento de Cástris temos a doação de uma escrava parda, de nome Maria, feita por Joana Barreta em memória do marido, Diogo Rodrigues. A doação teve lugar a 3 de outubro de 1605, na quinta da Pouca Farinha, com condição de as religiosas se servirem dela "portas adentro" ${ }^{57}$. Mas o que significavam estes serviços? Há dados para a Espanha e para a Sicília ${ }^{58}$

${ }^{55}$ Para algumas instituições masculinas também se verificam doações. Em 1576, Brites de Canha, doou um seu escravo, Aleixo, de cerca de 20 anos "por justos Respeitos que a isso moverão em espeçiall per desejar sua sallvaçam e lhe parecer que assi a podia ganhar (...) ao Reitor, padres e collegio do espirito santo da companhia de Jesus desta cidade d'evora que ora são e pelo tempo forem para serviço da dita casa (...) para que se sirvam delle e façam dele tudo o que quiserem.”. Arquivo Distrital de Évora, Fundo Notarial de Évora, Livro 191, fls. 38, 38v., 39. De teor semelhante, uma doação entre vivos valedoura, foi feita na igreja do Espinheiro em 1631 por Ana de Moura, que doou ao convento Gaspar, um seu escravo de 5 anos, para serviço da Casa e religiosos dele, impondo, que não fosse tirado da casa nem do mosteiro, nem vendido ou trocado para outro convento ou parte alguma. Arquivo Distrital de Évora, Fundo Notarial de Évora, Livro 564, fl. 101. Ainda no Espinheiro, em abril de 1585, o prior Frei João de Penamacor e outros religiosos da instituição passaram Carta de alforria a um escravo do convento. Assim, forraram a António, homem preto, de 60 anos pouco mais ou menos, de bom corpo, meio branco, mas com a condição de que não podia ir, viver, morar ou aproximar-se até duas léguas da herdade da Junceira (em Évoramonte, a única das que o convento possuía e que os frades administravam diretamente). ADE, Notariais, Livro 256, fls. 20-21 (informação esta que agrademos ao Dr. Manuel Branco).

Também D. Teotónio de Bragança, que protegeu particularmente os frades cartuxos e a sua instalação na cidade, doou um seu escravo, Jorge de Sousa, cerieiro, ao convento da Cartuxa. De facto, concedida a alforria, o escravo deveria assegurar o fornecimento de cera gratuitamente ao convento. Jorge Fonseca, Os escravos em Évora no século XVI..., cit., p. 32.

${ }^{56}$ Jorge Fonseca, Os escravos em Évora no século XVI.

${ }^{57}$ BPE, Cód. CXXXI/2-2, fl. 158 v.

58 Aymard, Maurice Aymard, "Il commercio dei grani nella Sicilia del' 500" Archivio Storico per la Sicilia Orientale, Anno LXXII, Fascicolo I-III, (1976), p.7-28, Discussion, p.32; Bernard Vincent, "L'esclavage en milieu rural espagnol au XVIIe siècle: l'exemple de la région d'Alméria", in Figures de l'esclave au Moyen Age et dans le monde moderne, L'Harmattan, Paris, 1996, p.165-176. 
que apontam no sentido de uma tendência para a redução da escravatura privada em detrimento da pública durante o período moderno, e que a escravatura em meio rural típica do período medieval deu lugar à doméstica urbana, sendo os escravos usados em casa e crescendo o seu número de acordo com o estatuto social do proprietário. Estes estudos indicam ainda que o trabalho dos escravos domésticos dependia do sexo e do meio: em meio rural, as mulheres serviam na cozinha, limpezas, serviços e os homens trabalhando nos campos ou na pastorícia. Na cidade, a diferenciação de género era menos acentuada (homens também nas limpezas), verificando-se mesmo o desempenho de alguns ofícios (alfaiate); esta diferenciação prolongar-se-ia para o universo monástico feminino, de acordo também com os locais de implantação das comunidades, sendo vedado o espaço da clausura ao escravo, não à escrava.

A presença de escravas na clausura, contrariamente à questão das criadas particulares ou da Ordem, passou discreta na documentação emanada dos órgãos centrais das ordens religiosas. No caso de Cister, as Juntas e Capítulos efetivamente pouco se debruçaram sobre a questão das escravas, contrariamente às exigências para a admissão de moças ou criadas: em 1737, exigia-se que fossem maiores de 12 e menores de 25 anos, sendo que a aceitação de moças particulares só se efetivava após saírem as antigas, não sendo aceites moças que já tivessem servido noutra Congregação ${ }^{59}$. Já em 1721, para tomar criada, as religiosas deviam respeitar a cláusula de depositar dinheiro suficiente para alguém, designado pelo Abade Geral, inquirir da sua reputação $0^{60}$, ou mesmo determinando superiormente o seu número. Porém, a Junta de 1742 constatou que em alguns mosteiros femininos cistercienses, muitos dos leitos destinados a religiosas estavam ocupados por recolhidas, criadas ou mesmo escravas, sob o pretexto de os terem comprado, determinando o abandono de tal prática num prazo de nove dias. No entanto, só em 1751 temos verdadeiramente um documento significativo:

“Ordena o N. Rmo. E mais Padres do Definitório que nenhuma Religiosa de hoje em diante possa ter Negra ou Mulata que a sirva nem ainda com o pretexto de ficar por sua morte ao mosteiro para o comum porque caso que assim suceda alguma vez sera em idade tão avançada que não sirva para mais do que ter o mosteiro de sustentala e esta mesma ley se praticara também com as educandas e recolhidas $\mathrm{E}$ a respeito das que hoje ha em alguns Mosteiros

\footnotetext{
${ }^{59}$ BPE, Cód.CXXXI/2-7, fl. 57.

${ }^{60}$ BPE, Cód.CXXXI/2-7, fl. 42.
} 
se lansarão fora por qualquer leve causa quando sua Senhora a não lanse no tempo que lhe asignar." ${ }^{1}$.

No seguimento desta determinação, Frei Manuel Barbosa, Abade Geral da Congregação de Alcobaça, em 1756, devido a um Breve do Núncio do reino, dá provisão $0^{62}$ para se recolherem no mosteiro de Cástris Helena da Exaltação, mulher de Pedro Lima Corado como recolhida e sua filha, Maria Romana do Pilar, como educanda, moradoras em Avis e naturais de Vila Rica. A mãe daria de piso 120.000 réis e a filha 80.000 réis, em pagamento faseado, bem como meias propinas de noviças às religiosas e religiosos. Se levassem criada ou escrava, dariam por ela de piso 60.000 réis.

Um dos casos mais interessantes que analisámos foi a admissão para recolhida de Lourença Dias de Jesus no convento de clarissas de N. ${ }^{a} \mathrm{Sr}^{\mathrm{a}}{ }^{\mathrm{a}} \mathrm{de}$ Aracoeli, de Alcácer do Sal, a 12 de dezembro de $1733^{63}$. Lourença era natural do bispado do Rio de Janeiro, freguesia de Santo António de Itatiaia, e surge identificada no contrato como mulata do Brasil, e escrava de Miguel Dias de Sousa, implicando a sua entrada no convento o pagamento de 300.000 réis e não dos 100.000 réis habituais. O processo contém o Indulto Apostólico da Sagrada Congregação de Bispos e Regulares para entrar na clausura do convento e viver em hábito secular, o termo de aceitação do Indulto e a tradução do Indulto. O notário Apostólico de Évora, Manuel Soares da Cunha, constituiu o processo, onde consta uma petição e um Despacho do Dr. Manuel Álvares Cidade, Provisor e Vigário Geral do Arcebispado de Évora, e um Breve Apostólico de Clemente XII. Na análise do processo, sublinha-se que era costume o convento receber religiosas de hábito secular, que tinha lugares vagos, e ainda que Lourença tinha posses para se sustentar, sendo aceite em Capítulo pela comunidade em 1735. A perceção deste processo só ganha maior significado quando o associamos á da entrada simultânea no mosteiro das três filhas de Lourença como educandas, Maria da Conceição (14 anos), Josefa de Jesus (7 anos) e Ana Maria de Jesus (4 anos) ${ }^{64}$; o pai era Miguel Dias de Sousa. O processo das educandas é acompanhado de certidão de nascimento, também no Brasil, sendo que na certidão da primeira filha, Maria da Conceição, Lourença é identificada como solteira e escrava de Miguel de Sousa, sendo-lhe concedida a alforria com o nascimento desta filha. As três irmãs conseguem ainda colocar no mosteiro uma criada que haviam trazido do Brasil, Francisca

\footnotetext{
${ }^{61}$ BPE, Cód. CXXXI/2-6, peça 6.

${ }^{62}$ BPE, Livro 20 Fundo S. Bento, doc. 60.

${ }^{63}$ ADE, CEEVR, SC K, SSC KA, 0015, Cx. 1.

${ }^{64}$ ADE, CEEVR/K-A/001/00012; CEEVR/K-A/001/00013; CEEVR/K-A/001/00016.
} 
de Santo António, a pretexto de as servir, e alegando sempre posses para o seu sustento, não dependendo da Casa franciscana.

Sublinhamos ainda que as cartas de alforria podem ser entendidas como bastante reveladoras da relação entre o proprietário e quem o servia; uma dessas cartas foi dada em Évora em 1577 por Inês Rodrigues ${ }^{65}$, viúva de Baltasar Fernandes. Inês confirmou que

"era verdade que ela tinha e avia hum seu escravo Indio per nome francisco de cor baça que ora sera em hydade de cinquenta annos, comprido de corpo que falla arrazoadamente E que ora dizia que deste moto proprio e livre vontade forrava ora avia por forro e livre ao dito francisco para que d'oje em diamte em os dias da vida do dito francisco elle posa fazer e fara de sy o que the aprouver como o fazem e podem fazer os homens que livres são e devem ser lyvres nascerão".

A alforria foi concedida a troco de 25.000 reais em dinheiro, logo recebidos, apelando Inês a que as justiças de Portugal e Castela não duvidassem da liberdade de Francisco. Neste contexto, não podemos também deixar de citar o caso de Catarina de Figueiredo de Almeida, solteira, que, em 25 de agosto de 1613, na Mouraria, declarou que tinha um escravo pardo alto, de 21 anos, bexigoso de rosto, e que estava determinado em ir em romaria ao reino de Castela "a nosa senhora de agoa de Lupe E depois de feyta sua Romaria querya corer o dito Reyno de castella e ver todas has couzas delle E nelle trabalhar no offisio de allfayate de que he ofisial a qual Romarya e yda elle dito manoell de figeredo não podia fazer sem lysença e consentimento de sua senhora" ${ }^{6}$. Ela concede-lhe essa licença para ir a Guadalupe e andar e trabalhar em Castela por 3 anos, obrigando todos os seus bens; o escravo Manuel aceitou a licença, obrigando-se a voltar ao fim desse tempo para casa da sua senhora. $\mathrm{O}$ documento é assinado pelo tabelião e testemunhas, bem como pelo escravo, que sabia escrever, mas não por Catarina, que não sabia escrever. É, pois, um documento em que fica explícita, em inícios do século XVII, a confiança no escravo mesmo para fora do reino, escravo que, além de saber assinar, era alfaiate; naturalmente, fica também clara a importância da romaria a Espanha neste período, em pleno domínio filipino, o que também facilitaria a circulação do escravo entre os dois reinos.

\footnotetext{
${ }^{65}$ BPE, Cód. CLXIX 1-26, No 7.

${ }^{66}$ ADE, Notarial de Évora, Livro 397, fl. 93.
} 


\section{Considerações finais}

Durante o período moderno em Évora também os mosteiros e conventos registam a presença de escravos, uma realidade que, se aumenta exponencialmente no período moderno, encontra experiências mais ancestrais a nível europeu e extraeuropeu. Ao serviço das instituições ou de religiosas particulares, passavam a fazer parte do quotidiano dos mosteiros por via de partilhas, legados testamentários, heranças, sentenças, doações (operações mais frequentes nos casos que analisámos). Esta presença não atingiu números muito significativos, ideia que nos fica do cruzamento de fontes analisadas em relação a diferentes casas religiosas. Essas fontes são escassas e as referências a escravos/as na clausura surgem diluídas nos conjuntos documentais. Sabendo-se da sua existência, torna-se difícil apurar com exatidão o número de religiosas que traziam para os conventos não só criadas particulares mas especialmente escravas, de molde a dar a conhecer a experiência quotidiana da vida conventual. São raros os autores que trabalham estes dados, como o faz Silvia Evangelisti ${ }^{67}$. No caso português, trata-se certamente de uma questão em aberto e a desenvolver em futuras abordagens, colocando interrogações sobre o quebrantar da clausura, a não abdicação da propriedade, a manutenção das desigualdades no claustro, e, muito especialmente, da vida de escravos de ambos os sexos no mesmo mosteiro (caso específico dos mosteiros e conventos femininos, admitindo os espaços religiosos masculinos apenas escravos masculinos), em espaços que podemos considerar como permeáveis e de fácil contacto com o mundo extraclausura.

${ }^{67}$ Silvia Evangelisti, Nuns: A history of convent life 1450-1700, OUP, Oxford, 2007. 